\title{
Recently resurrected for European liverwort flora - Frullania calcarifera Steph., new addition for the Crimean Peninsula
}

\author{
Eugene A. Borovichev ${ }^{1,2} \&$ Anna A. Vilnet ${ }^{1}$ \\ ${ }^{1}$ N.A. Avrorin Polar-Alpine Botanical Garden-Institute of Kola Science Centre RAS, Apatity, 184209, Russia \\ ${ }^{2}$ Institute of the Industrial Ecology Problems of the North of the Kola Science Center of RAS, Apatity, 184209, Russia \\ E-mail: borovichyok@mail.ru
}

\begin{abstract}
Frullania calcarifera is a long forgotten taxon, which originally has been described by F. Stephani in 1887 from Portugal, but largely overlooked since that time due to its synonymization with $F$. tamarisci s.str. Based on both molecular and morphological data, F. calcarifera is here for the first time recorded for the Crimean liverwort flora. A morphological description and figures are provided and differentiation, ecology and distribution are discussed.
\end{abstract}

Keywords: Frullania tamarisci complex, liverworts, integrative taxonomy, distribution

\section{INTRODUCTION}

The genus Frullania Raddi consists of approximately 300-375 species (Frey \& Stech, 2009; Hentschel et al., 2009). In the Holarctic, one of the most morphologically malleable group is F. tamarisci (L.) Dumort. s.l. that is reflected in ambiguities in taxa delimitation and their systematic position (Hattori, 1972; Crandall-Stotler et al., 1987; Heinrichs et al., 2010). During the recent molecular study of $F$. tamarisci s.1. in Russia, four lineages were recognized and separated at species rank (Vilnet et al., 2014). Unexpectedly, one of them with specimens identified by morphology as F. nisquallensis Sull., revealed remote affinity to $F$. tamarisci s.l. and a new species, F. subarctica Vilnet, Borovich. et Bakalin, was described (Vilnet et al., 2014). Three other lineages were found in the F. tamarisci s.1. clade. The specimens classified as $F$. tamarisci s.str. and F. appendiculata Steph. were located in related clades. A single specimen from the Crimean Peninsula provisionally assigned to $F$. tamarisci $\mathrm{s}$.str. differs genetically from multiple samples of $F$. tamariscis.str. from the Caucasus and Kola Peninsula. After combination of ITS1-2 nrDNA and trnL-F cpDNA nucleotide sequence data with those obtained by Heinrichs et al. (2010), the specimens from the Crimean Peninsula showed relation to samples from Greece, Spain and Portugal named as $F$. calcarifera Steph. (Vilnet et al. 2014: Fig. 1). Frullania calcarifera is a long forgotten European taxon which originally has been described by F. Stephani (Stephani, 1887) from Portugal, but has been overlooked since that time due to its synonymization with $F$. tamarisci s.str. (cf. Müller, 1906-1911; Hattori, 1972; Sim-Sim, 1999). Based on both molecular and morphological data, $F$. calcarifera is here for the first time recorded for the Crimean liverwort flora. To attract attention to this poorly known species that undoubtedly should be found in other areas of the Mediterranean region. we provide figures and description, and discuss differentiation of this species from closely related taxa based on the Crimean specimen.

\section{MATERIALS AND METHODS}

More than 100 specimens from VBGI, KPABG, KW and JE identified as Frullania tamarisci s.1. were studied using standard light microscope. Mature main stems (not branches) were measured, and general diagnostic characters were pictured. The protocols of molecular study and phylogenetic trees were published in Vilnet et al. (2014).

\section{RESULTS}

Frullania calcarifera Steph., Hedwigia 26 (1): 1, 1887; Steph., Bol. Soc. Broteriana 5: 132, 1887.

\section{Description (Fig. 1)}

Plants in thin dense mats; lusterless, greenish to brownish green or golden green, often 


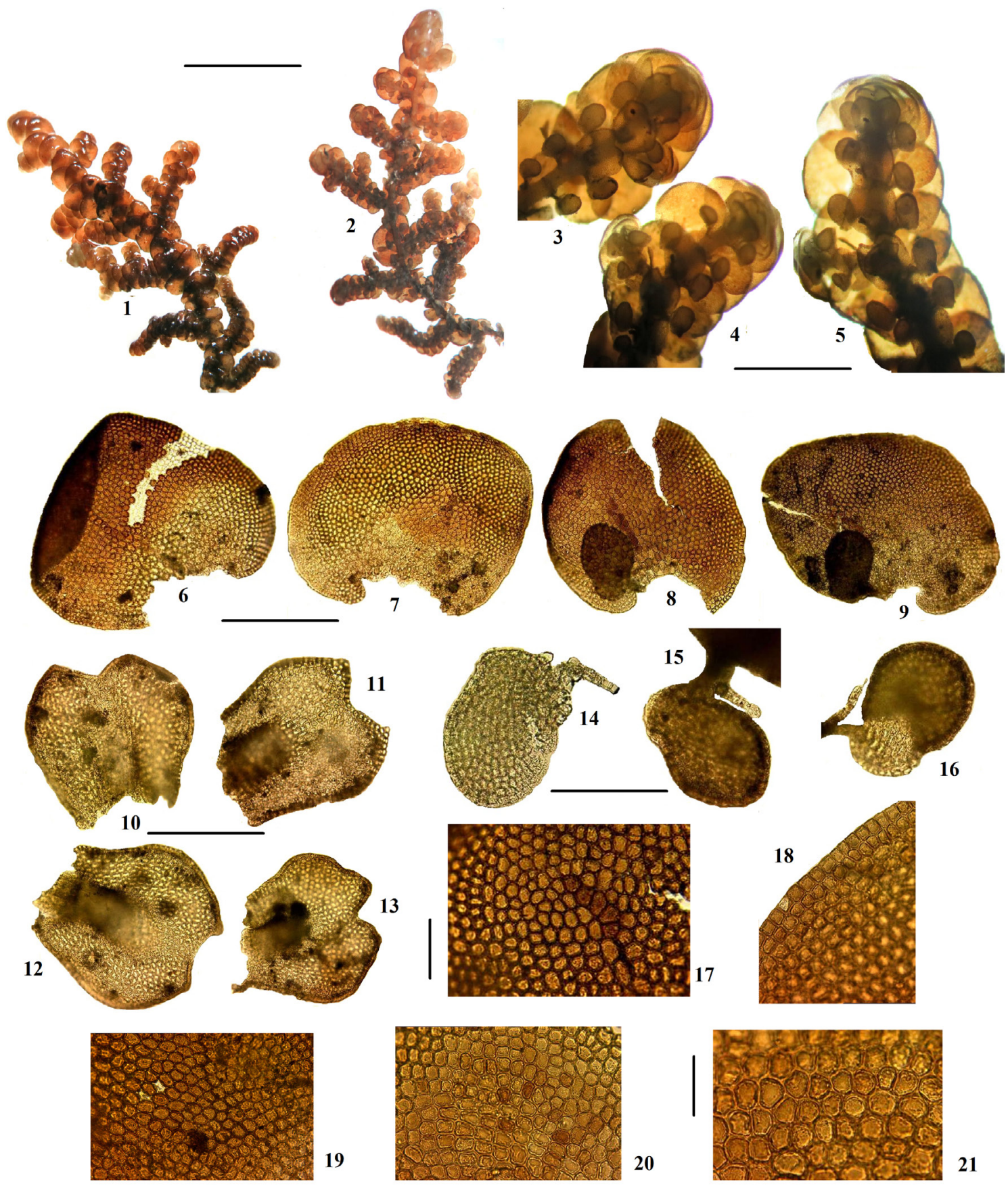

Fig. 1. Frullania calcarifera Steph. (from the Crimean Peninsula, 5.VI.1964, Partyka, s.n.): 1 - general habit (in dorsal view); 2 - general habit (in ventral view); 3-5 - part of shoot (in ventral view); 6-9 - dorsal lobes of leaves; 10-13 - underleaves; 14-16-lobules with styli; 17, 20-21 - cells of median part of dorsal lobe; 18 - cells of margin of dorsal lobe; 19 - cells of basal part of dorsal lobe. Scale bars: $5 \mathrm{~mm}$ for 1-2; $0.9 \mathrm{~mm}$ for 3-5; $300 \mu \mathrm{m}$ for $6-16 ; 30 \mu \mathrm{m}$ for $17-20$; $50 \mu \mathrm{m}$ for 21 . 
with reddish brown secondary pigmentation, never blackish. Leafy shoots (0.8-)1.2-1.3 $\mathrm{mm}$ wide and 8-15(-22) $\mathrm{mm}$ long, pinnately to bipinnately branched; branches with leaves becoming gradually smaller downward. Dorsal lobes imbricate, entire, \pm reniform to broadly or oblique ovate to cordate; $0.4-0.6 \mathrm{~mm}$ long and $0.5-0.8 \mathrm{~mm}$ wide; apices often incurved, broadly rounded; antical base cordate, auriculate; cells of leaf margin \pm subquadrate, $6-8(-10) \mu \mathrm{m}$, median cells of leaf lobe usually isodiametric or subisodiametric (8-)10-12(-14) × (10-)12-16 $\mu \mathrm{m}$, usually with slightly thickened walls and trigones lacking or small; basal leaf cells paler in color; ocelli \pm rounded, (12-)14-16(-18) $\mu \mathrm{m}$ in diameter, absent or forming a short line of 2-5 cells long or with a few scattered ocelli. Lobule cylindrical to obovate, saccate, slightly constricted at base; apex rounded; $0.4-0.5 \mathrm{~mm}$ long and $0.28-0.36 \mathrm{~mm}$ wide; axis parallel to the stem; stylus small, subulate to filiform, 4-8 cells long and $1(-2)$ cells wide, but $1-3$ cells wide at base; sometimes ending in slime-papilla. Cuticle smooth. Underleaves oblong-quadrate to quadrate-ovate or oblong-obovate, $0.3-0.4$ $\mathrm{mm}$ long and $0.4-0.6 \mathrm{~mm}$ width, with slightly recurved margins, bilobed for $1 / 4-1 / 5$ (or less) of underleaf length, lobes obtuse to subacute, slightly to strongly auriculate at base. Leaf lobes of lateral branches smaller, apices often shortly acute; commonly with a \pm well-developed median line of ocelli. Rhizoids scarce, in fascicles at base of underleaves. Gemmae lacking. Dioicous. Male plants with a spherical-ovoid androecium at short lateral branches, consist of 3-6 pairs of closely imbricate bracts; subtending 2-3 antheridia, paraphyses lacking; bracteole flat, connate with one bract at base. In Crimean specimen no gynoecia is seen.

\section{Differentiation}

By morphology the species is recognized by the lusterless, greenish to brownish green or golden green colour with reddish brown secondary pigmentation, often incurved, broadly rounded dorsal lobe apex and a small, subulate to filiform stylus, 4-8 cells long and $1(-2)$ cells wide, but 1-3 cells wide at base, virtually without disk. In the field, $F$. calcarifera resembles other members of $F$. tamarisci s.1., but differs by smaller size and coloration. The differences between $F$. calcarifera and the morphologically similar Frul- lania species in the Russian liverworts flora are summarized in Table 1.

\section{Variation}

Studied specimens vary in size, coloration, length of ocelli line and shape of underleaves. The coloration of leafy shoots varies from greenish with reddish brown secondary pigmentation to brownish green or golden green. The bases of dorsal lobes in the Greek specimens are decolorate. Underleaves vary from oblong-quadrate to quadrate-ovate or oblong-obovate, with slightly recurved margins. The underleaves of the Portuguese specimen are oblong-quadrate with strongly recurved margins. Number and disposition of ocelli are considered as important features to distinguish taxa of $F$. tamarisci s.1. (Hattori, 1972; Crandall-Stotler et al., 1987; Heinrichs et al., 2010; etc), but in studied specimens this varies considerably. In the Crimean and Samothrake specimens, ocelli are absent or form a short line of $2-5$ cells, rarely with a few scattered ocelli. In the Portuguese and Rhodes plants, ocelli form a long line of 8-15 cells or rarely with a few scattered ocelli. These differencies may be explained by a wider morphological variability then suggested earlier.

\section{Ecology}

When Stephani (1887) described $F$. calcarifera the habitat was characterized as humid sandy soils or tree bark. The Portuguese and Greek specimens were collected from mineral substrata on dry sunny rocks (see studied specimens list). The Crimean specimen was collected on dry rock under dry conditions. All studied specimens of $F$. calcarifera grow in thin dense mats, closely attached to the substrate with admixture of mosses.

\section{Distribution}

As presently known, $F$. calcarifera is a Mediterranean species. The species was described from the vicinity of Coimbra in the Portugal (Stephani, 1887) and later found in Italy and Algeria (Stephani, 1898-1924). Based on molecular and morphological data it is known from Spain (Mallorca and Canary Islands), Greece (Samothraki and Rodos Islands) and southern Portugal (Algarve District) (Heinrichs et al., 2010) as well from the Crimean Peninsula. The map of current distribution supported by molecular data is given in Fig. 2. 
Table 1. The comparison of $F$. calcarifera with morphologically similar Frullania species distributed in Russia

\begin{tabular}{|c|c|c|c|}
\hline Feature & F. calcarifera Steph. & F. tamarisci (L.) Dumort. s.str. & F. appendiculata Steph. \\
\hline Coloration & $\begin{array}{l}\text { lusterless, greenish to brown- } \\
\text { ish green or golden green, } \\
\text { with reddish brown second- } \\
\text { ary pigmentation, never } \\
\text { blackish }\end{array}$ & $\begin{array}{l}\text { shiny, dark green with reddish brown } \\
\text { secondary pigmentation to dark } \\
\text { brown }\end{array}$ & $\begin{array}{l}\text { shiny to lusterless, deep } \\
\text { green to red brown and } \\
\text { green brown, sometimes } \\
\text { purplish and purple-brown }\end{array}$ \\
\hline Apex of dorsal lobes & broadly rounded & acute, $1-4$ cells length & $\begin{array}{l}\text { more or less apiculate to } \\
\text { acuminate }\end{array}$ \\
\hline Stylus and disk & $\begin{array}{l}4-8 \text { cells long and } 1(-2) \text { cells } \\
\text { wide, but } 1-3 \text { cells wide at } \\
\text { base, disc virtually absent }\end{array}$ & $\begin{array}{l}5-6(-8) \text { cells long, } 1-(2) \text { cells wide, } \\
\text { with well developed disk }\end{array}$ & $\begin{array}{l}3-8 \text { cells long and } 1-3 \text { cells } \\
\text { wide, with well developed } \\
\text { disk }\end{array}$ \\
\hline Linear ocelli & $\begin{array}{l}\text { absent or forming a short } \\
\text { line of } 2-5 \text { cells (to long line } \\
\text { of } 8-15 \text { cells in Portugalian } \\
\text { and Greek plants) or with a } \\
\text { few scattered ocelli }\end{array}$ & $\begin{array}{l}\text { very polymorphic patterns: } 1 \text { ) in } \\
\text { uniseriate } \pm \text { continuous line in lobe } \\
\text { middle, 2) ocelli in line in part } 2-3 \\
\text { cells wide, 3) ocelli in branched } \\
\text { line, 4) ocellate line accompanied by } \\
\text { solitary ocelli, 5) only scattered ocelli } \\
\text { present }\end{array}$ & $\begin{array}{l}\text { well developed, more than } \\
1 / 2 \text { of leaf length, mostly ca. } \\
2 / 3-3 / 4 \text { of leaf length }\end{array}$ \\
\hline Ecology & $\begin{array}{l}\text { thin dense mats, closely at- } \\
\text { tached to the substrate with } \\
\text { admixture of mosses on dry } \\
\text { rocks }\end{array}$ & $\begin{array}{l}\text { among other bryophytes or in pure } \\
\text { mats growing on rocks, boulders and } \\
\text { soil in old heathland and on bark of } \\
\text { trees }\end{array}$ & $\begin{array}{l}\text { commonly epiphytic, but } \\
\text { also epilithic, in broadleaved } \\
\text { to coniferous forests zones } \\
\text { or corresponding belts in } \\
\text { mountains distributed sout- } \\
\text { ward }\end{array}$ \\
\hline Distribution & $\begin{array}{l}\text { Europe, presumable Mediter- } \\
\text { ranean areas }\end{array}$ & $\begin{array}{l}\text { Europe (incl. Atlantic Islands) and } \\
\text { Asia (known from Turkey and Geor- } \\
\text { gia), in the New World known from } \\
\text { easternmost part of Boreal to Tem- } \\
\text { perate North America }\end{array}$ & $\begin{array}{l}\text { Boreal to Subtropical } \\
\text { Eastern Asia }\end{array}$ \\
\hline
\end{tabular}

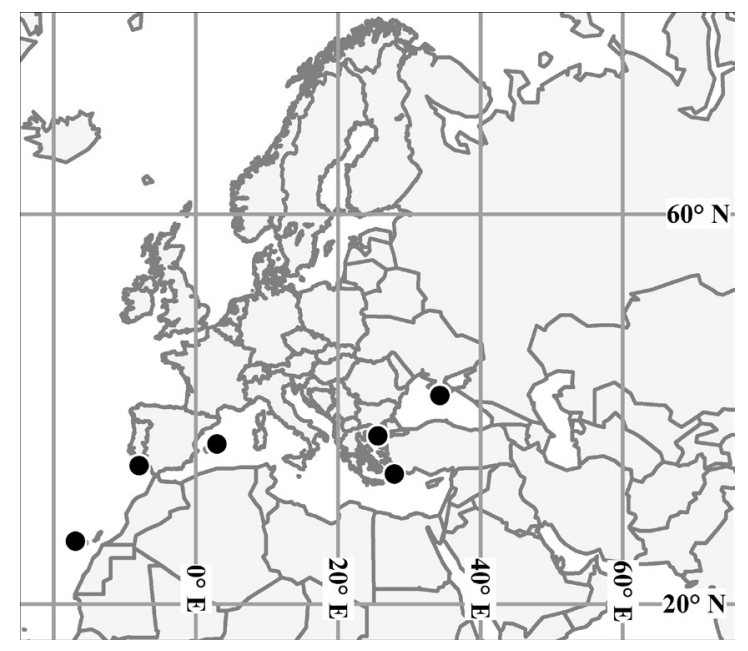

Fig. 2. Current distribution of Frullania calcarifera

\section{Selected specimens examined}

Frullania calcarifera Steph. Crimean Peninsula, Southern seashore of the Crimea, Ayudag Mt., $44^{\circ} 33^{\prime} 35^{\prime \prime} \mathrm{N}$, 34²0'0.65"E, 5 June 1964, L. Ya. Partyka, s.n. (KW-BH; duplicate in KPABG \#109378); PORTUGAL. Algarve, Serra de Monchique, Marmelete River valley, on sunny dry rock, 9 April 1996, Schäfer-Verwimp \& Verwimp 17507 (JE); GREECE, Rhodes Island, ca 6.8 $\mathrm{km}$ west of Eleousa, on northern slope in Cupressus forest, 13 May 2002, R. Düll, s.n. (JE); Northern Aegeian, Samothraki Island, on siliceous soil, 10 May 2004, R. Düll 1a (JE).

Frullania tamarisci (L.) Dumort. RUSSIA. Murmansk Province: Pechenga District, vicinity of Nickel', Orschoayjvi Mt., on dry rock, 21 June 2013, Borovichev 2-4-2013 (KPABG); Lapland State Biosphere Reserve, Monchegorsk District, Pel-tundra, on dry rock, 28 June 2008, Melekhin 29-3-08 (KPABG); Krasnodar Territory: Sochi National Park, Schahe River Basin, on Abies trees, 3 October 2008, Konstantinova K4321-08 (KPABG); ibidem, Bzhizhu River, aul Tchagapsch Vicinty, on base of sand rock, 22 November 2011, 
Konstantinova \& Savchenko K322-2-11 (KPABG); Karachaevo-Cherkessian Republic: Teberda River Basin, left bank of Azgek River, on stony slope of stream, on rock, 19 September 2005, Konstantinova K539-5-05 (KPABG); Dagestan Republic: Charodinskijy District, Nuckatal Range, valley of confluent of Kara-or River, on rock under mosses, 7 March 2011, Konstantinova K35b-11 (KPABG); ibidem, Uruh-Sota Settlement Vicinity, on rock, 7 March 2011, Konstantinova K442-11 (KPABG). GEORGIA. Adjaria: Mtirala National Park, bark of tree, 11 May 2013, Bakalin G-11-55-13 (VBGI), cliffs in open place, 12 May 2013, Bakalin, G-12-32-13 (VBGI).

Frullania appendiculata Steph. RUSSIA. Sakhalin Province: Kunashir Island, the bark of Abies on the height 1-2 $\mathrm{m}$ from the ground, 7 September 2006, Bakalin K-47-16-06 (VBGI); Sakhalin Island, Korsakovsky District, crevice filled by fine-grained soil in vertical N-facing dry cliffs, 16 September 2009, Bakalin S-66-12-09 (VBGI); Primorsky Territory: Lazovsky District, more or less dry boulders on slope in part shade, 08 September 2010, Bakalin P-42-1210 (VBGI); Partizansky District, crevices among stones in gravelly barrens field, 10 September 2010, Bakalin P-44-11-10 (VBGI); Khabarovsk Territory: Nanajsky District, Tardoki-Yani Range, cliff ledge, 29 August 2012, Barkalov, s.n. (VBGI); REPUBLIC OF KOREA. Deokgyusan: shaded stone in broadleaved forest, 24 June 2008, Bakalin Kor-7-10-08 (VBGI); KyongNam Province: dry stones along stream, 13 June 2009, Bakalin Kor-2-23-09 (VBGI); ChonNam Province: wetted stone near stream, 20 June 2009, Bakalin Kor22-17-09 (VBGI); JAPAN. Honshu: Ouchi-dani Park, tree trunk, 10 March 2013, Bakalin J-1-22-13 (VBGI).

\section{ACNOWLEDGEMENTS}

We are greatly indebted to the curator of JE (Dr. H.-J. Zündorf) for specimen loans. Mr. A.N. Savchenko is thanked for preparing of maps. We thank Dr. V.A. Bakalin and Prof. N.A. Konstantinova as well as the reviewers for valuable comments. This study was partially supported by the Russian Foundation for Basic Researches (grants no. 15-29-02662, 15-04-03479).

\section{REFERENCES}

Crandall-Stotler, B., Stotler, R.E. \& Geissler, P. 1987. A biosystematic study of the subspecies of Frullania tamarisci (L.). Bryologist 90: 287-308. http:// dx.doi.org/10.2307/3243091

Frey, W. \& Stech, M. 2009. Marchantiophyta, Bryophyta, Anthocerotophyta. In: Frey, W. (ed.): Syllabus of Plant Families. Borntraeger, Stuttgart. $1-257$.

Hattori, S.1972. Frullania tamarisci-complex and the species concept. J. Hattori. Bot. Lab. 35: 202-251.

Heinrichs, J., Hentschel, J., Bombosch, A., Fiebig, A., Reise, J., Edelmann, M., Kreier, H.-P., SchäferVerwimp, A., Caspari, S., Schmidt, A., Zhu, R.-L., von Konrat, M., Shaw, B. \& Shaw, A.J. 2010. One species or at least eight? Delimination and distribution of Frullania tamarisci (L.) Dumort. s.1. (Jungermanniopsida, Porellales) inferred from nuclear and chloroplast DNA markers. Molec. Phylogenet. Evol. 56: 1105-1114. http://dx.doi. org/10.1016/j.ympev.2010.05.004

Hentschel, J., von Konrat, M., Pócs, T., Schäfer-Verwimp, A., Shaw, A.J., Schneider, H. \& Heinrichs, J. 2009. Molecular insights into the phylogeny and subgeneric classification of Frullania Raddii (Frullaniaceae, Porellales). Mol.. Phyl. Evol. 52: 142-156. http://dx.doi.org/10.1016/j. ympev.2008.12.021

Müller, K. 1906-1911. Die Lebermoose Deutschlands, Oesterreichs und der Schweiz, 1. Abteilung, Leipzig.

Sim-Sim, M. 1999. The genus Frullania Raddi (Hepaticae) in Portugal and Madeira. Cryptog. Bryol. 20: $83-144$.

Stephani, F. 1887. Ueber einige Lebermoose Portugals. Hedwigia 1: 1-6.

Stephani, F. 1898-1924. Species Hepaticarum. 6. Supplementum ad. Vol. 1-5. Publication de l'Institut Botanique et Herbier Boissier, Genève.

Vilnet, A.A., Borovichev, E.A. \& V.A. Bakalin 2014. Frullania subarctica - a new species of the Frullania tamarisci complex (Frullaniaceae, Marchantiophyta). Phytotaxa 173 (1): 61-72. http:/ / dx.doi. org/10.11646/phytotaxa.173.1.5 
Folia Cryptog. Estonica 